\title{
Impacts of forest conversion and agriculture practices on water pathways in Southern Brazil
}

\author{
Jérémy Robinet $^{\mathrm{a}^{*}}$, Jean P.G. Minella ${ }^{\mathrm{b}}$, Cláudia A. P. de Barros ${ }^{\mathrm{c}}$, Alexandre Schlesner ${ }^{\mathrm{b}}$, Andreas \\ Lücke $^{\mathrm{d}}$, Yolanda Ameijeiras-Mariño ${ }^{\mathrm{e}}$, Sophie Opfergelt ${ }^{\mathrm{e}}$, Jan Vanderborght ${ }^{\mathrm{a}, \mathrm{d}}$, Gerard Govers ${ }^{\mathrm{a}}$ \\ ${ }^{a}$ Division of Geography and Tourism, Department of Earth and Environmental Sciences, KU Leuven, Leuven, \\ Belgium \\ ${ }^{\mathrm{b}}$ Department of Soil, Universidade Federal de Santa Maria, Rio Grande do Sul, Brazil \\ ${ }^{\mathrm{c}}$ Department of Agronomy, Universidade Federal do Rio Grande do Sul, Rio Grande do Sul, Brazil \\ ${ }^{\mathrm{d}}$ Institute of Bio- and Geosciences, IBG-3: Agrosphere, Forschungszentrum Jülich GmbH Jülich, Germany \\ ${ }^{\mathrm{e}}$ Earth and Life Institute, Environmental Sciences, Université catholique de Louvain, Belgium \\ * Corresponding author at: Division of Geography and Tourism, Department of Earth and Environmental \\ Sciences, KU Leuven, Leuven, Belgium. E-mail address: jeremy.robinet@kuleuven.be (J. Robinet)
}

Keywords: Critical Zone, Subtropical environment, Land use/cover change, water pathways, environmental tracers

\section{$\underline{\text { Abstract }}$}

Land use/cover change (LUCC), and more specifically deforestation and multi-decadal agriculture, is one of the various controlling factors of water fluxes at the hillslope or catchment scale. We investigated the impact of LUCC on water pathways and stream stormflow generation processes in a subtropical region in southern Brazil. We monitored, sampled and analyzed stream-, pore-, subsurface- and rainwater for dissolved Silicon concentration (DSi) and ${ }^{18} \mathrm{O} /{ }^{16} \mathrm{O}\left(\delta^{18} \mathrm{O}\right)$ signature to identify contributing sources to the streamflow under forest and under agriculture

Both forested and agricultural catchments were highly responsive to rainfall events in terms of discharge and shallow groundwater level. DSi vs. $\delta^{18} \mathrm{O}$ scatter plots indicated that for both land use types, two runoff components contributed to the stream discharge. The presence of a dense macropore network, combined with the presence of a compact and impeding B-horizon, led to rapid subsurface flow in the forested catchment. In the agricultural catchment, the rapid response to rainfall was mostly due to surface runoff. A two-component isotopic hydrograph separation indicated a larger contribution of event water to total event runoff in the agricultural catchments. We attributed this increase to a decrease in topsoil hydraulic conductivity associated with agricultural practices. The chemical signature of the old water component in the forested catchment was very similar to that of the shallow groundwater and the pore soil water: it is therefore likely that the shallow groundwater was the main source of old water. This is not the case in the agricultural catchments where the old water component had a much higher DSi concentration than the shallow groundwater and the soil pore water. As the agricultural catchments were larger, this may to some extent simply be a scale effect. However, the higher water yields under agriculture and the high DSi concentration observed in the old water under agriculture suggest a significant contribution of deep groundwater to catchment runoff under agriculture, suggesting that LUCC may have significant effects on weathering rates and patterns. 


\section{Introduction}

The dynamics, extent and consequences of land use/cover changes (LUCC) have been intensively studied for several decades (Lambin et al., 2003; Foley et al., 2005). Some of its impacts, such as a significant contribution to anthropogenic carbon emissions (Houghton et al., 2012), soil degradation (Lal, 2001; Vanacker et al., 2007), loss in biodiversity (HainesYoung, 2009) or changes in regional climate through changes in water balance and energy budgets (Webb et al., 2005; Salazar et al., 2015), are now well documented.

LUCC can also have an impact on the hydrological cycle. Most studies indicate an increase in water yields after conversion of forest to agricultural land (e.g. Hibbert, 1967; Brown et al., 2005; Molina et al., 2012; Dias et al., 2015), with a greater impact in high-rainfall areas such as (sub) tropical environments (Bosch and Hewlett, 1982). The increase in annual streamflow is mainly linked to an increase in baseflow due to reduced evapotranspiration (ET), especially in the dry periods (Blackie and Edwards, 1979; Dias et al., 2015). The results compiled by Bruijnzeel (2004) indicate that changes in stormflow contribute only to a lesser extent to the observed changes in water yield.

LLUC does not only affect total runoff amounts, but also causes changes in stormflow and runoff pathways. These changes will in turn affect other processes. Several studies have highlighted the importance of a strong hydrologic control of solute fluxes (Chappell et al., 2007; Godsey et al., 2009; Clymans et al., 2013; Van Gaelen et al., 2014; Ameli et al., 2017). Water pathways and fluid residence time are also a primary control on chemical weathering rates (Maher, 2010; Brantley et al., 2017; McIntosh et al., 2017). Thus, changes in water pathways due to LUCC will not only affect the functioning but also the further evolution of the Critical Zone (CZ - Anderson et al., 2007; Brantley et al., 2007; Brooks et al., 2015). Understanding these changes is therefore critical for our understanding of the impact that natural and human-induced LUCC may have on CZ functioning and development.

Elsenbeer and Vertessy (2000) presented a first conceptual framework of preferential water pathways in humid forested ecosystems based on series of case studies. They observed a predominance of lateral pathways within the soils, mostly caused by changes of soil hydraulic conductivity with depth. Bonell (2004) applied this framework to tropical environments and highlighted the importance of subsurface stormflow (SSF), as already observed in temperate forested catchments by other authors (e.g. McDonnell., 1990; Sidle et al., 2001; Blume et al., 2008). This rapid SSF is linked to the presence of soil macropores and pipes in the upper soil horizon, due to roots and biological activity (Uchida et al., 2001; Bachmair and Weiler, 2011; Beven and Germann, 2013). Macropores, high top soil infiltration rates and the presence of perched water tables are probably also the cause of the higher frequency of saturation overland flow compared to infiltration excess overland flow in forest environments (Elsenbeer and Vertessy, 2000; Bonell, 2004; Germer et al., 2010).

Only a limited number of studies investigated the impact of LUCC on stormflow pathways in a (sub) tropical setting (Bonell, 2004). Generally, studies report an increase in overland flow when the forest cover is reduced (Sandstrom, 1996; Ziegler et al., 2004; Chandler, 2006; Moraes et al., 2006; Germer et al., 2010; Muñoz-Villers and McDonnell, 2013; Salemi et al., 2013). In most cases, this is due to an increase in infiltration excess overland flow (Ziegler et al., 2004; Chandler, 2006; Germer et al., 2010; Muñoz-Villers and McDonnell, 2013) but an increase in both saturation and infiltration overland flows is also possible (Moraes et al., 2006). This change in stormflow generation has often been associated with larger quick flow volumes being measured over the long term for agricultural catchments (Grip et al., 2004; Moraes et al., 2006; Muñoz-Villers and McDonnell, 2013). These changes are linked to the 
impact of LUCC on soil properties, more specifically to a decrease of the soil saturated hydraulic conductivity $\left(\mathrm{K}_{\mathrm{sat}}\right)$ (Godsey and Elsenbeer, 2002; Bonell, 2010; Don et al., 2011). Zimmermann et al. (2006) measured a reduction of $\mathrm{K}_{\text {sat }}$ with increasing land use intensity, especially at the soil surface, leading to a strong increase of the probability of surface runoff for large rainfall events. The reduction in $\mathrm{K}_{\text {sat }}$ following forest conversion is due to the reduction in macro-porosity (Zhou et al., 2002) and the increase in bulk density (BD) caused by the compaction and crusting associated with agricultural practices (Sandstrom, 1996; Don et al., 2011). While all studies showed an increase in stormflow after forest conversion, they reported very different magnitudes of change and identified different mechanisms of stormflow generation (e.g. Sandstrom, 1996; Chaves et al., 2008; Germer et al., 2010; Muñoz-Villers and McDonnell, 2013). More research is therefore needed to better estimate the impact of LUCC on stormflow generation and to evaluate the effect of changes in soil properties on event water contribution to streamflow (Bonell, 2004).

Most studies on the hydrological effects of LUCC made use of environmental tracers to assess changes in the water balance and in the provenance of the stream water (Kendall and McDonnel, 1998). Stable isotopes of oxygen (e.g. Muñoz-Villers and McDonnell, 2013) and hydrogen (e.g. Uhlenbrook et al., 2008) are very effective tools to infer water origin, pathways, movement or residence time (Sklash, 1990). Other chemical constituents, such as dissolved organic carbon (DOC - e.g. Van Gaelen et al., 2014) or dissolved silica (DSi - e.g. Stewart et al., 2007), have also been used. A major advantage of DSi as tracer is its low and negligible concentration in precipitation (Stewart et al., 2007; Clymans et al., 2013), providing a clear contrast with old water (Kendall and McDonnel, 1998).

Thus, while we do have a basic understanding of how forest conversion may affect hydrological processes and pathways in (sub) tropical environments, the magnitude of change caused by LUCC as well the impact of these changes on solute fluxes and weathering remain poorly constrained for many environments. The objective of our study was therefore to evaluate the impact of deforestation and multi-decadal land degradation through agriculture in a subtropical area in southern Brazil with the combined use of oxygen stable isotopes of water and DSi. By comparing a forested catchment with limited human disturbances with a catchment converted to agricultural land at the beginning of the 20th century, we aim at improving the understanding of LUCC effects on stormflow generation in this environment. More specifically, we try to evaluate whether forest conversion led to a greater delivery of stormflow through more rapid flow paths.

\section{Material and Methods}

\subsection{Study area}

Our study site is located in the Brazilian state of Rio Grande do Sul. It was initially covered by the Atlantic Forest which extended along the Atlantic coast of Brazil and, to a varying extent, also its inland (Morellato and Haddad, 2000). Following colonization and conversion to agricultural land use from the beginning of the 20th century onwards (Morellato and Haddad, 2000; Lopes, 2006), the forested area was reduced to $12 \%$ of its original area by 2005 (Ribeiro et al., 2009). In Rio Grande do Sul, the deforestation process was accelerated around 1960 after the introduction of cash crops like tobacco or soybean (Lopes, 2006).

We selected two small catchments located $15 \mathrm{~km}$ apart within the Guapore river basin: a 0.03 $\mathrm{km}^{2}$ forested catchment (FOC - Fig. 1, 28 49'58.93"S 52 $12^{\prime} 45.76 " \mathrm{O}$ ) and a $1.19 \mathrm{~km}^{2}$ agricultural catchment (ARC - Fig. 1, 28 $8^{\circ} 55^{\prime} 53.41^{\prime \prime S} 52^{\circ} 6^{\prime} 33.65^{\prime \prime} \mathrm{O}$ ). We also studied a 0.14 $\mathrm{km}^{2}$ subcatchment of ARC (ARCsub - Fig. 1). All catchments are located on the edge of the 
Basalt Plateau of the Paraná Basin (Renne et al., 1992; Vieira et al., 2015). The lithology is mostly composed of rhyolitic and rhyodacitic rocks, although basaltic rocks dominate at lower altitudes (Caner et al., 2014; Vieira et al., 2015). The average monthly temperature varies between 12 to $22^{\circ} \mathrm{C}$ (averages from 2002 to 2017). The precipitation is well distributed along the year, without a dry season. The average annual rainfall is $1944 \pm 336 \mathrm{~mm}(2002-2017$ average). There is some seasonal variability of the rainfall intensity, with shorter and more intense rains during the spring and summer seasons (September to March) (Ramon et al., 2017).

FOC (Fig. 1) is located within a remnant of the original Atlantic forest. Its smaller catchment area is linked to the impossibility of finding larger intact fragments of the Atlantic Forest. The catchment witnessed only minor anthropogenic impacts due to its preservation by successive owners. It is only recently (around 10 years ago) that erva mate (Ilex paraguariensis) was planted in-between the native vegetation in a partial shade growing system (Eibl et al., 2000). Cultivation in the ARC catchment (Fig. 1) started around the beginning of the $20^{\text {th }}$ century. As a result, it has today a heterogeneous land use, with areas cultivated for tobacco (Nicotina tabacum), soybean (Glycine max), maize (Zea mays), black oats (Avena strigose) and some erva-mate (Ilex paraguariensis). Some parts of the catchment are also occupied by reforested eucalyptus (Eucalyptus spp.), pasture and small rural properties. Poor agricultural practices, combined with steep slopes, have been causing considerable soil erosion and degradation (Minella et al., 2009). To reduce the soil erosion and the sediment delivery to the water system, soil conservation practices (e.g. minimum tillage system) have been introduced since 1990s in governmental development programs (Minella et al., 2008b).

Soils in the forest can be classified as Acrisols and possess well-defined organic matter and Argic horizons (Fig. 2a). Some Leptosols can be found on the steepest slopes of the catchment. The soil depth is $1.33 \pm 0.97 \mathrm{~m}$ on average, with large differences $(0.01$ to $>4 \mathrm{~m})$ depending on the slope, which varied from 2 to $17^{\circ}$. The upper part of the ARC catchment, where ARCsub is located, has a gentle rolling topography. The soils are deep $(>4 \mathrm{~m})$ and classified as Acrisols (Fig. 2c - Barros et al., 2014). The slope range in the ARC catchment is $0.03-58^{\circ}$ while it is only of $0.1-21^{\circ}$ in the ARCsub catchment. The lower part of the catchment is indeed more incised into the basalt plateau and slopes are shorter and steeper. The soils on these slopes are shallower $(0.01$ to $1.55 \mathrm{~m})$ and mainly consist of Leptosols. Cambisols are found in limited parts of the agricultural catchments (Barros et al., 2014). The soils under both forest and agriculture are also not in direct contact with the bedrock as there is a thick layer of saprolite at the soil-bedrock interface (Fig. 2). In all catchments, an important characteristic of the Acrisol is the well-defined transition between the overlaying horizons and the Argic B horizon (Fig. 2). The latter has a much lower $\mathrm{K}_{\text {sat }}$ and higher BD (Fig. 2b,d) and there is therefore a clear discontinuity in water infiltration rate (Barros et al., 2014; Barros, 2016). We observed this B horizon at an average depth of $90 \mathrm{~cm}$ in all areas with sufficient soil depth for it to develop. Compared to agricultural sites, top soils under forest have a lower BD (Fig. 2b,d) and a higher $\mathrm{K}_{\text {sat }}$ (Fig. 2b,d - Barros, 2012, 2016) .

\subsection{Hydrometeorological measurements monitoring and sampling}

We selected slopes with contrasting topographies and land uses for the installation of monitoring equipment and detailed soil analyses. The FOC gentle (FOG) and steep (FOS) slopes (Fig. 1) possess overall similar characteristics in terms of soil texture (Table 1). The gentle slope in the ARC catchment (ARG) is cultivated with soybean during summer. In recent years, a minimum tillage practice has been combined with a cover crop with black oat (Avena strigosa) during the winter period. The steep slope (ARS) is under tobacco cultivation with intensive conventional soil tillage and no cover crop in winter. ARS has lower clay 
content and higher sand content compared to ARG (Table 1). ARG is located in the upper part of the catchment. ARS is located just outside the border of ARC, but possesses similar characteristics to the adjacent steep slopes in the lower part of the catchment.

We monitored rainfall using a pluviograph installed at a meteorological station in ARCsub (Fig. 1). We collected rainfall samples manually during rainfall events to avoid any fractionation due to evaporation at rainfall collectors installed at the outlet of FOC and ARC. We collected samples on 17 and 20 occasions in FOC and ARC respectively. We measured streamflow using Parshall flumes located at the outlet of each catchment (FOC, ARC, and ARCsub) (Fig. 1). We recorded water levels every 5 min using ISCO 720 Submerged Probe Flow Modules connected to ISCO 6712 Full-size Portable Samplers (Teledyne Isco, Nebraska, USA). We used flow-proportional sampling above a given threshold discharge for each catchment $\left(0.28,114.72\right.$ and $4.47 \mathrm{ls}^{-1}$ for FOC, ARC and ARCsub, respectively). At the same locations, we collected samples manually during baseflow conditions, on average once a week. Between August and November 2015, we collected 63, 76 and 104 samples for FOC (7 events), ARCsub (14) and ARC (8), respectively. For some large events in FOC, we were unable to accurately monitor the discharge due to flume overflow.

To extract soil pore water along topographic transects in each selected slope, we installed suctions cups with a porous membrane of $0.45 \mu \mathrm{m}$ pore size (Eijkelkamp, The Netherlands) at two depths (30 and 70cm) and three positions: Bottom (B), Middle (M) and Top (T) of the slopes (Fig. 1). In FOG, given the greater slope length, we replaced the middle position by a Lower Middle (LM) and an Upper Middle (UM) position (Fig. 1). We sampled each position nine time on average from August to October in 2015 but suction samples could not be taken at each time from all samplers as the soil was sometimes too dry. On average, we collected six samples per suction cup.

To sample the shallow groundwater, we also installed observation wells in different topographic positions in FOG (FOGB, FOGUM, FOGT), FOS (FOSB, FOSM) (Fig. 1), ARG (ARGB, ARGM, ARGT) and ARS (ARSB, ARST) (Fig. 1). Due to logistical issues, we could not install observation wells in ARSM and FOST. The bottom depth of the observation wells corresponded to the soil-saprolite interface. For deeper soil profiles, we decided to reach a maximum depth of $2.50 \mathrm{~m}$. The observation wells were screened over the lower $1.0 \mathrm{~m}$. We recorded water level every 5-min using Mini-Divers (Eijkelkamp, The Netherlands) and we corrected them for atmospheric pressure using a Baro-Diver (Eijkelkamp, The Netherlands) installed in ARGT. We took shallow groundwater samples manually from the observation wells during dry and rainfall conditions between August and October 2015. On average, we sampled each observation well seven times during that period. Given the characteristics of the observation wells installed, and more specifically their screened length, it is not possible to use those data to discriminate hydraulic heads at different depths along the screen. Instead, they measure an integrated water pressure along the entire screened length.

\subsection{Laboratory analysis}

We filtered all water samples with $0.45 \mu \mathrm{m}$ polycarbonate filters within a day of sampling and kept them sealed at $3^{\circ} \mathrm{C}$ before analysis. We analysed the samples for DSi concentration (DSi) by ICP-AES at the Earth and Life Institute, Environmental Sciences, Université Catholique de Louvain (Belgium) for the pore water samples and at the Institute of Bio- and Geosciences, IBG-3: Agrosphere, Forschungszentrum Jülich GmbH (Germany) for the river and shallow groundwater samples.

We analysed all water samples for oxygen isotopic signature at the Institute of Bio- and Geosciences, IBG-3: Agrosphere, Forschungszentrum Jülich GmbH (Germany) with cavity 
ring-down spectroscopy (L2130-I, Picarro Inc., Santa Clara, CA, USA). We measured water samples together with internal laboratory standards calibrated against international isotopic reference materials (Brand et al., 2014). The isotopic compositions are expressed as $\delta$-values in per mil (\%) as follows:

$$
\delta=\left(R_{\text {sample }} / R_{\text {standard }}-1\right) * 1000
$$

with $R_{\text {sample }}$ and $R_{\text {standard }}$ as isotope ratios $\left({ }^{18} \mathrm{O} /{ }^{16} \mathrm{O}\right)$ of sample and standard, respectively. Isotope values are normalized to the Vienna Standard Mean Ocean Water (VSMOW) Vienna Standard Light Antarctic Precipitation (VSLAP) scale. Analytical precision as determined from internal standards was better than $\pm 0.08 \%$. We only analysed rainfall samples for $\delta^{18} \mathrm{O}$, as DSi in rainfall is typically negligible (Laudon and Slaymaker, 1997; Holloway and Dahlgren, 2001; Blecker et al., 2006; Clymans et al., 2013) and was considered as null in the subsequent analyses. We realized the statistical comparison between different groups using the Kruskal-Wallis test.

\subsection{Two-component hydrograph separation}

Stable isotopes have been widely used to perform hydrograph separation (see reviews of Buttle, 1994, and Klaus and McDonnell, 2013). Based on results obtained through the analysis of the environmental tracers (see 3.2), a two-component hydrograph separation method appeared to be best suited to infer the contribution of the major water pathways. Twocomponent isotopic separations can be used to infer the contribution of pre-event and event water to the streamflow via the following equations:

$$
\begin{aligned}
& Q_{t} C_{t}=Q_{p} C_{p}+Q_{e} C_{e} \\
& X=\left(C_{t}-C_{p}\right) /\left(C_{e}-C_{p}\right)
\end{aligned}
$$

where $Q, C$ and $X$ are the discharge, concentration and event fraction of the streamflow, respectively, and the subscript $t, p$ and $e$ represent the total streamflow, the pre-event and event components, respectively. We used the average $\delta^{18} \mathrm{O}$ signature of baseflow samples to characterize pre-event water and the average $\delta^{18} \mathrm{O}$ signature of the rain during every rainfall event to characterize new water. We calculated the relative contribution of event water to the streamflow for each stream water sample collected. We calculated the uncertainty of the twocomponent hydrograph separation using the method developed by Genereux (1998). This method is based on the application of a general uncertainty propagation technique. We performed all the analyses presented in the study in the MATLAB environment (MathWorks, 2015)

\section{Results}

\subsection{Hydrological measurements}

The total amount of rainfall $(668.6 \mathrm{~mm})$ during the monitoring period (August - November $2015)$ was slightly higher than the average amount observed in other years $(549.4 \pm 157.4 \mathrm{~mm})$, as was the total annual rainfall amount in $2015(2496.45 \mathrm{~mm})$ compared to the 2002-2014 average (1901.0 $\pm 549.4 \mathrm{~mm})$. The first half of the monitoring period was relatively dry: during this period, discharges in FOC were very low or even zero. It highlighted the non-perennial status of the stream. All catchments had significantly different mean standardized discharges $\left(\mathrm{FOC}=2.7 \pm 6.6, \mathrm{ARCsub}=4.0 \pm 10.6\right.$ and $\left.\mathrm{ARC}=3.7 \pm 10.3 \mathrm{~mm}^{-1} \mathrm{day}^{-1}\right)$. Median values of the standardized discharges also showed higher discharges for ARCsub (1.1 mm day $\left.{ }^{-1}\right)$ and ARC 
$\left(1.2 \mathrm{~mm} \mathrm{day}^{-1}\right)$ compared to FOC $\left(0.6 \mathrm{~mm} \mathrm{day}^{-1}\right)$. Both high and low flows in FOC were lower than in ARCsub and ARC. All catchments were highly responsive to rainfall events (Fig. 3a), with a very short time delay between the rainfall and the peak in streamflow. Shallow groundwater levels rose quickly in all fields and catchments after rainfall events (Fig. $3 b)$.

\subsection{Tracer signatures and relations with discharge}

DSi concentrations in stream water were significantly lower in FOC $\left(4.1 \pm 1.5 \mathrm{mg} \mathrm{l}^{-1}\right)$ than in ARCsub $\left(10.0 \pm 2.9 \mathrm{mg}^{-1}\right)$ and ARC $\left(8.3 \pm 2.4 \mathrm{mg} \mathrm{l}^{-1}\right)$. For ARCsub and ARC, the stream water DSi concentration was significantly higher than the shallow groundwater DSi concentration $\left(3.4 \pm 0.3 \mathrm{mg} \mathrm{l}^{-1}\right)$ and the soil pore water DSi concentration $\left(3.4 \pm 0.7 \mathrm{mg} \mathrm{l}^{-1}\right)$ This was not systematically the case in FOC (groundwater: $4.8 \pm 0.6$ and soil pore water: $6.0 \pm 2.1 \mathrm{mg} \mathrm{l}^{-1}$ ). We address possible reasons for this difference in the subsequent discussion. Shallow groundwater and soil pore water DSi concentrations were significantly higher in FOG $\left(4.3 \pm 0.5,6.6 \pm 2.9 \mathrm{mg} \mathrm{l}^{-1}\right)$ and FOS $\left(5.3 \pm 0.7,5.4 \pm 1.3 \mathrm{mg} \mathrm{l}^{-1}\right)$ than in ARG $(3.1 \pm 0.3,3.4 \pm 0.8$ $\left.\mathrm{mg}^{-1}\right)$ and ARS $\left(3.6 \pm 0.7,3.4 \pm 0.6 \mathrm{mg} \mathrm{l}^{-1}\right)$. We could not identify any distinct spatial patterns in DSi concentration along the different slopes for either shallow groundwater or soil pore water (not shown).

We observed a dilution of stream DSi with increasing discharge for all catchments (Fig. 4). For every catchment, we observed a linear relation in log-log space with a slope coefficient well higher than $-1(-0.1,-0.17$ and -0.16 for FOC, ARCsub and ARC respectively). Thus, the DSi dilution was not directly proportional to the increase in stream discharge. In FOC, some samples had a considerably lower DSi concentration than other samples collected at similar middle-range discharges. These samples corresponded to stream peak discharges occurring after a relatively dry period with only small rainfall events (on 17-09-2015 (15.52mm), 08-10$2015(18.77 \mathrm{~mm})$ and $20-10-2015(15.16 \mathrm{~mm}))$. Prior to these events, the groundwater levels were very low, below the sensing depth of the observation wells.

Stream discharge $(-4.83 \pm 0.85,-4.19 \pm 0.86$ and $-4.23 \pm 0.94 \%$ for ILO, ARCsub and ARC, respectively) and shallow groundwater $(-4.17 \pm 0.88,-5.30 \pm 0.95,-4.47 \pm 1.39,-3.72 \pm 0.80 \%$ o for FOG, FOS, ARG and ARS, respectively) had relatively similar isotopic signatures while the $\delta^{18} \mathrm{O}$ signature of the soil pore water was in general significantly lower $(-5,77 \pm 0,76$, $5,50 \pm 0,80,-5,60 \pm 1,22$ and $-5,65 \pm 1,06 \%$ for FOG, FOS, ARG and ARS, respectively). While having a similar mean value, the stream $\delta^{18} \mathrm{O}$ signature of FOC was then also significantly lower than for ARC and ARCsub, as for the DSi concentrations.

The $\delta^{18} \mathrm{O}$ signature of the rainfall $(-2.66 \pm 1.56 \%$ ) was significantly higher than the respective $\delta^{18} \mathrm{O}$ signature of all other hydrological components. The opposite is often observed due to isotope fractionation because of evaporation (Kendall and McDonnel, 1998; Leibundgut et al., 2009). We attributed our observations to seasonal variations of the $\delta^{18} \mathrm{O}$ signature in the precipitation. The $\delta^{18} \mathrm{O}$ signature measured at the Global Network of Isotopes in Precipitation (GNIP) station of Porto Alegre (150 km East from our study site) during the period of the year corresponding to our sampling period (August - November) is similar to what we measured in the rainfall $(-3.10 \pm 1.19 \%)$. The average rainfall $\delta^{18} \mathrm{O}$ signature in the months prior to this period is much lower $(-5.25 \pm 1.60 \%$ on average for May, June and July). This suggests that the groundwater and pore water consisted of a temporally integrated mixture of recent and older rainwater. Accordingly, the input of ${ }^{18} \mathrm{O}$ enriched rainfall led to an increase of the stream water $\delta^{18} \mathrm{O}$ signature with increasing discharge in all catchments (Fig. 4). The relationship of $\delta^{18} \mathrm{O}$ with stream discharge was weaker than for the stream DSi-discharge 
relationships (Fig. 4), especially for ARC. This can be attributed to the temporal variability of the $\delta^{18} \mathrm{O}$ rainfall signature.

We did not perform measurement to evaluate the potential changes in the isotopic signature of the rain in FOC caused by interception of the vegetation. However, there was no significant difference between the $\delta^{18} \mathrm{O}$ signature of the precipitation collected in FOC $(-2.80 \pm 1.69 \%)$ compared to the precipitation collected in $\operatorname{ARC~(-2.74~} \pm 1.81 \%$ ).

\subsection{DSi and $\delta^{18}$ O relations}

Looking more closely at the DSi and $\delta^{18} \mathrm{O}$ signature relationship (Fig. 5), it appeared that the relationship between stream DSi and $\delta^{18} \mathrm{O}$ signature during a single rainfall event was similar for all catchments. At low discharges, DSi was high and $\delta^{18} \mathrm{O}$ signatures converged to similar low values for all events. During a rainfall event, stream water composition varied mainly along a single line towards lower DSi and a higher $\delta^{18} \mathrm{O}$ signature. We fitted individual linear regressions for each rainfall event using the corresponding stream water samples. Using the obtained equations, we extrapolated the $\delta^{18} \mathrm{O}$ signature corresponding to zero DSi (which we assumed to be representative for the rainfall). The comparison of measured and extrapolated rainfall $\delta^{18} \mathrm{O}$ signature not only showed a very high correlation and $\mathrm{R}^{2}$ for ARCsub $(0.90)$ and $\mathrm{ARC}(0.91)$, but the extrapolated $\delta^{18} \mathrm{O}$ values were also very similar to the values measured for the rainfall of the same event (Fig. 6). The correlation was weaker for FOC $\left(\mathrm{R}^{2}=0.58\right)$ but the trend was similar despite the lower number of observations.

In FOC, we observed a counter-clockwise hysteresis loop for stream DSi and a clockwise hysteresis loop for stream $\delta^{18}$ O signature (Fig. 7a). Meanwhile, in ARCsub (Fig. 7b) and ARC (Fig. 7c), we observed for most event clockwise and counter-clockwise loops for DSi and $\delta^{18} \mathrm{O}$ signatures, respectively. However, for some large rainfall events (not shown), hysteresis loops similar to FOC were observed in ARC.

\subsection{Hydrograph separation}

We applied a two-component hydrograph separation of stream discharge to all stream samples used in the DSi vs. $\delta^{18} \mathrm{O}$ signature analysis (Fig. 5). We obtained total contribution of event water to the streamflow of $46.0 \pm 3.7 \%$ in FOC, $52.9 \pm 10.6 \%$ in ARCsub and $60.3 \pm 11.2 \%$ in $\mathrm{ARC}$ for the sampled events. Thus, while the contribution of event water was important in all catchments, it was more important in ARCsub and ARC than in FOC. The maximum contribution of new water to the streamflow often corresponded to the peak discharge (Fig. $7 \mathrm{~d}$, e, f) and was on average $53.5 \pm 13.3 \%$ in FOC, $59.6 \pm 1.2 \%$ in ARCsub and $67.9 \pm 1.0 \%$ in ARC. The correlation coefficient $\left(\mathrm{R}^{2}\right)$ between discharge and the fraction of event water was 0.57 in FOC, 0.69 in ARCsub and 0.66 in ARC.

\section{Discussion}

\subsection{Changes in water yield after deforestation}

Our data indicate that conversion of forest to agricultural land led to an increase in streamflow, with, in particular, higher baseflow volumes in ARCsub and ARC in comparison with FOCError! Reference source not found. These results should be considered with care given the relatively short monitoring period compared to other similar studies (e.g. Molina et al., 2012; Muñoz-Villers and McDonnell, 2013). However, other studies in comparable environments observed similar increase in streamflow, with the greatest change associated with the baseflow component and attributed to lower ET in non-forested catchments (Bosch and Hewlett, 1982; Bruijnzeel, 2004; Dias et al., 2015). The small size of the FOC catchment could also have caused a lower baseflow volume through catchment leakage or losses to deep 
groundwater, two processes that can affect small headwater catchments in particular (Bruijnzeel, 1989; Niedzialek and Ogden, 2012). The smaller contributing area to the stream in ILO could also lead to a smaller channel initiation (Montgomery, 1994), and hence lower discharge compared to ARC and ARCsub.

More data and longer measurement periods are required to improve the estimation and quantification of changes in water yield after deforestation. Monitoring the catchments during the summer period would also provide valuable information given potential ET variability over the year (varying from approximately 40 to $150 \mathrm{~mm} / \mathrm{month}$, calculated using New LocClim (FAO, 2005; Grieser et al., 2006)), changes in field coverage due to agriculture practices (Barros et al., 2014) or varying rainfall intensities (Ramon et al., 2017).

\subsection{Water pathways changes after LUCC}

The small peak flow response time (Fig. 3) and the similar DSi dilution (Fig. 4) observed in all catchments suggested that LUCC did not lead to a drastic change in water pathways. However, visual observations showed that important changes did take place: during rainfall events, no surface runoff occurred in FOC, contrary to the two agricultural catchments (Fig. $8 \mathrm{a})$. We only observed surface runoff in FOC during the largest, most intense rainfall events. In addition, sediment concentrations were clearly higher in the stream water in the agricultural catchments. Such observations were indications that LUCC in our study area did have an impact on water pathways. The combined use of DSi and $\delta^{18} \mathrm{O}$ signature scatterplots, hysteresis loops and two-component hydrograph separations allowed us to better understand the differences in hydrological processes between the different catchments. We used these observations to build a conceptual model of the hydrological pathways under forest and agricultural land uses (Fig. 9).

First, the near-linear relationship between DSi concentration and $\delta^{18} \mathrm{O}$ signature we found in all catchments (Fig. 5 and 6) supported the use of a 2-component model to describe water dynamics. Evidently, this linear relationship is no proof: it only shows that, while in principle three components can be distinguished using two tracers, we can only identify two from our data. During an event, stream water was composed of a mixture of a pre-event component (Fig. 9a.0, b.0) characterized by high DSi and a low $\delta^{18} \mathrm{O}$ signature and of an event component characterized by low DSi and a high $\delta^{18} \mathrm{O}$ signature. We identified the latter as the direct contribution of the event rainfall. This hypothesis is supported by the close correspondence of the rainfall $\delta^{18} \mathrm{O}$ and the extrapolated $\delta^{18} \mathrm{O}$ from the DSi and $\delta^{18} \mathrm{O}$ signatures in the stream discharge (Fig. 6). In FOC, DSi concentration and $\delta^{18} \mathrm{O}$ signature of the pre-event baseflow component were similar to the composition of the pore water and shallow groundwater (Fig. 5Fig. 6). In ARCsub and ARC however, the pre-event component was more enriched in DSi than the pore water and shallow groundwater.

The two-component hydrograph separation results demonstrated an important direct contribution of event water to the streamflow in all catchment during rainfall events. We also observed both a fast rise and a fast recession of the shallow groundwater levels after rainfall events (Fig. 3b), indicating a quick displacement of the water in the soil. These observations combined suggest rapid subsurface flow was a major process contributing to peak discharges in all catchments (Fig. 9a.1, b.2b). The first reason for such significant subsurface flow was most likely the presence of a clay-rich water-impeding B-horizon in most locations in all the catchments (Fig. 2a). This causes a discontinuity in the $\mathrm{K}_{\text {sat }}$ profile of the soil leading to the generation of a perched water table and lateral subsurface flow (Elsenbeer and Vertessy, 2000; Godsey et al., 2004; McDaniel et al., 2008). The importance of discontinuity in the soil profile in our study area was already highlighted by the modelling approach of de Barros et al. 
(2014). Under forest, this discontinuity in further enhanced by the presence of macropores associated to the dense channel network left behind by decayed roots (Uchida et al., 2001; Bachmair and Weiler, 2011; Beven and Germann, 2013).Visual observations in opened soil pits confirmed the role of these macropores in the rapid delivery of subsurface water to the streams (Fig. 8b).

The higher contribution of event water observed in ARCsub and ARC is explained by the lower infiltration rates under agricultural land use,leading to the generation of surface runoff (Fig. 9b.2a). de Barros (2016) measured top soil $\mathrm{K}_{\text {sat }}$ almost five times larger under native forest $\left(980.59 \mathrm{~mm} \mathrm{~h}^{-1}\right)$ than under agricultural land $\left(198.78 \mathrm{~mm} \mathrm{~h}^{-1}\right)$. Surface runoff could however not be distinguished or separated from the shallow subsurface flow using DSi and $\delta^{18} \mathrm{O}$ signature as tracers. Besides visual observations, much higher sediment concentrations in agricultural catchments support the importance of surface runoff on agricultural land, with values typically reaching around $1200 \mathrm{mg} \mathrm{l}^{-1}$ during peak discharges (Minella et al., 2008a; Barros et al., 2014). No sediment concentration data were available for the forested catchment, but the well-established links between soil conservation practices and sediment yield in ARC (Merten and Minella, 2006; Merten et al., 2010) constitute a fair indicator of the importance of surface runoff in agricultural catchments in our study area. Similar impacts of deforestation and agriculture have been observed in multiple cases and, as in our study, were often associated to a decrease in surface $\mathrm{K}_{\text {sat }}$ due to agricultural practices (Zhou et al., 2002; Moraes et al., 2006; Muñoz-Villers and McDonnell, 2013; Salemi et al., 2013).

The analysis of the hysteresis loops (Fig. 7) showed opposite hysteresis evolution results during small and moderate events for FOC on one hand and ARCsub and ARC on the other hand. It appeared that the contribution of event water to streamflow at the beginning of a rainfall event was higher in FOC than in ARCsub or ARC. We believe the main reason for these opposite temporal evolutions was the scale difference between the catchments. The agricultural catchments are larger than the forested catchment so that new event water needed more time to reach the stream. The old water dominating the hydrograph in the beginning of rainfall events in the agricultural catchment is likely coming from wet areas closer to the stream (Fig. 9b.1 - McDonnell, 1990; McGlynn and McDonnell, 2003; Clymans et al., 2013). In ARC, the hysteresis loop was reversed during the largest rainfall events, which also occurred after a very wet period. The higher contribution of event water at the beginning of an event, similarly to FOC, may be due to a larger generation of surface runoff during these events, which reduced travel times due to greater water depths and overland flow velocities.

Under forest, the presence of a dense network of macropores allowed rapid SSF, bypassing the soil matrix. This explains why the proportion of older water richer in DSi was higher during the falling limb of the hydrograph. The old water was delivered more slowly to the catchment outlet than new event water (Fig. 9a.2). Such direct feeding of subsurface flow by precipitation was also observed by Kienzler and Naef (2008). During the falling limb, rapid SSF became less important and the contribution of old water, displaced by event water infiltrating in the soil matrix, became more important.

The saturation overland flow we observed in the forested catchment during very intense rainfall events can be expected to have a chemical signature similar to that of rapid SSF and therefore cannot be distinguished from the latter (Fig. 9a.3).

\subsection{Higher DSi export from agricultural catchments}

We observed relatively large differences in DSi concentrations between catchments with different land uses. Overall, we measured much lower DSi concentrations in the streamflow under forest. We have shown that in all catchments the event component consisted mainly of 
new water with low DSi (see 4.2). The difference in DSi in stream water was therefore mainly due to a difference in baseflow conditions. We also observed that the stream DSi concentration was also significantly higher than the shallow groundwater and the soil pore DSi concentrations in ARC and ARCsub, but not in ILO. This is a clear indication that, in ARCsub and ARC, a baseflow discharge component with a high DSi concentration was present, the source of which we did not measure directly in this study. The most likely candidate for the presence of such DSi-rich water is a deep groundwater component.

A possible explanation for the presence of this deep groundwater component in ARC and ARCsub and not in FOC is catchment size. In the larger catchments, flow paths with longer residence times may be present (McGlynn et al., 2003; McGuire et al., 2005) and lead to higher DSi concentrations (Maher, 2010, 2011). These flow paths may also drain deeper substrate with different weathering signatures, as suggested by Germanium-Silicon (Ge-Si) ratio analyses (Ameijeira-Mariño, 2017). However, we need longer time series of isotopic data to better quantify the catchment residence times.

Another possibility might be an increased DSi mobilization following deforestation (Conley et al., 2008; Struyf and Conley, 2012). Topsoils under agriculture in our study area are indeed depleted in biogenic Si (BSi) compared to forest (Unzué-Belmonte et al., 2017). The lower DSi concentration in soil pore water in agriculture compared to forest is probably related to this BSi depletion. It is however unlikely that this is the main mechanism in the catchments we studied. An increased DSi production in the topsoil would also lead to high DSi during peak flow, which we did not observed. It is more likely that the reduction in ET due to deforestation (Blackie and Edwards, 1979; Dias et al., 2015) has led to a significant increase in soil moisture and deep water percolation. Deep-water percolation will be further enhanced by the destruction of the topsoil macropore network under agriculture. This deep water may drain less weathered substrates from which more DSi can be mobilized through weathering. Observations on the Ge-Si ratio in the different catchments are consistent with this hypothesis (Ameijeira-Mariño, 2017).

\section{Conclusion}

Hydrological measurements and tracer analysis allowed us to build a conceptual model of how water pathways in the study area responded to forest conversion. Under both land use types, a two-component model can explain the basic characteristics of the rainfall-runoff response: an old water component, enriched in DSi and with a lower $\delta^{18} \mathrm{O}$ signature and new water, which is essentially the direct contribution of the event rainfall to event runoff. Both under agriculture and under forest there is a very quick response of runoff to rainfall. Under both land uses, a decrease in DSi concentration and a rising $\delta^{18} \mathrm{O}$ signature accompany the rise in discharge.

At first sight, it therefore appears that, in our study area, LUCC does not have a strong impact on water dynamics. However, this broad similarity hides important differences. Under forest, we rarely observed overland flow and the rapid response of runoff to rainfall can be attributed to rapid subsurface flow. On agricultural land, agricultural practices destroyed the macropore network that allows for rapid subsurface flow. Here, the rapid response is due to overland flow generation, which leads to a significant sediment export from agricultural catchments. It also explains the higher total contribution of event water to the stream discharge in the agricultural catchments compared to the forested catchment. The geochemical signature of the stream water suggested that rapid subsurface flow travels rapidly, leading to counterclockwise hysteresis for DSi. The fact that clockwise hysteresis was observed under agricultural land use 
(at least for moderate events) is likely to be related to the larger surface area of the agricultural catchments.

While the chemical characteristics of the baseflow from the forested catchment were very similar to those of the pore water and the shallow groundwater (suggesting that the latter may be the reservoir producing most of the base flow), this was not the case for the catchments under agriculture. Here the baseflow was much more strongly enriched in DSi than the pore water and shallow groundwater. This enrichment is unlikely to be related to an enhanced dissolution of DSi in the topsoil as the latter would also result in high DSi concentrations in the pore water. It is much more likely that this water is coming from a deep groundwater source. The importance of this deep groundwater source under agricultural land use may again be related to catchment size, but it is also likely that deep groundwater flow has become more important after forest conversion due to (i) a reduction in ET and (ii) the destruction of the macropore network within the topsoil. The fact we measured a significantly higher standardized water yield under agriculture in comparison to forest also suggests that the reduction in ET due to forest conversion is important.

Our study confirms that LUCC does not only affect the overall water balance but has also implications with respect to the pathways that water follows through the landscape. Understanding how such changes affect weathering patterns and rates remains an important challenge that needs to be addressed if to understand how human activities affect the Critical Zone.

\section{Acknowledgments}

We would like to thank the other members (L. Ávila, T. Canale, R. Ramon, F. Schneider) of the team of the Department of Soils of the University of Santa Maria (RS, Brazil) for their help regarding the preparation of the field campaigns, the monitoring and the collection of the samples. We also thank B. Campforts, L. Fondu, and M. Van de Broek from the Department of Earth and Environmental Sciences of the Katholieke Universiteit Leuven (Belgium) for the measurement of the of the soil texture. Y. Ameijeiras-Mariño and J. Robinet were supported by the Belgian Science Policy Office (BELSPO) in the framework of the Inter University Attraction Pole SOGLO - The soil system under global change project (P7/24). Cláudia A. P. de Barros and Alexandre Schlesner were supported by the National Council for Scientific and Technological Development (CNPq).

\section{References}

Ameijeira-Mariño Y. 2017. Chapter 6: Contribution from deeper mineral weathering to streams after forest conversion to cropland: tracing with $\mathrm{Ge} / \mathrm{Si}$. In Impact of forest conversion to cropland on soil weathering: a geochemical study at the pedon, slope and catchment scales (PhD the.Université catholique de Louvain (UCL, Belgium).

Ameli AA, Beven K, Erlandsson M, Creed IF, McDonnell JJ, Bishop K. 2017. Primary weathering rates, water transit times, and concentration-discharge relations: A theoretical analysis for the critical zone. Water Resources Research 53: 942-960 DOI: 10.1002/2016WR019448

Anderson SP, von Blanckenburg F, White AF. 2007. Physical and chemical controls on the Critical Zone. Elements 3 (5): 315-319 DOI: 10.2113/gselements.3.5.315

Bachmair S, Weiler M. 2011. New Dimensions of Hillslope Hydrology. In Forest Hydrology and Biogeochemistry, Synthesis of Past Research and Future Directions: 455-481. DOI: 
Barros CAP. 2012. Comportamento hidrossedimentológico de uma bacia hidrográfica rural utilizando técnicas de monitoramento e modelagem (Master thesis dissertation).Universidade Federal de Santa Maria (UFSM, RS, Brazil).

Barros CAP. 2016. Dinâmica Dos Escoamentos Na Modelagem Da Produção De Sedimentos Em Uma Pequena Bacia Rural (PhD thesis dissertation).Universidade Federal de Santa Maria (UFSM, RS, Brazil).

Barros CAP, Minella JPG, Dalbianco L, Ramon R. 2014. Description of hydrological and erosion processes determined by applying the LISEM model in a rural catchment in southern Brazil. Journal of Soils and Sediments 14 (7): 1298-1310 DOI: 10.1007/s11368-014-0903-7

Beuselinck L, Govers G, Poesen J, Degraer G, Froyen L. 1998. Grain-size analysis by laser diffractometry: Comparison with the sieve-pipette method. Catena 32 (3-4): 193-208 DOI: 10.1016/S0341-8162(98)00051-4

Beven K, Germann P. 2013. Macropores and water flow in soils revisited. Water Resources Research 49 (6): 3071-3092 DOI: 10.1002/wrcr.20156

Blackie JR, Edwards KA. 1979. General Conclusions From the Land Use Experiments in East Africa. East African Agricultural and Forestry Journal 43:sup1: 273-277 DOI: 10.1080/00128325.1979.11662968

Blecker SW, McCulley RL, Chadwick OA, Kelly EF. 2006. Biologic cycling of silica across a grassland bioclimosequence. Global Biogeochemical Cycles 20 (3): 1-11 DOI: 10.1029/2006GB002690

Blume T, Zehe E, Bronstert A. 2008. Investigation of runoff generation in a pristine, poorly gauged catchment in the Chilean Andes II: Qualitative and quantitative use of tracers at three spatial scales. Hydrological Processes 22 (18): 3676-3688 DOI: 10.1002/hyp.6970

Bonell M. 2004. Runoff generation in tropical forests. In Forest, Water and People in the Humid Tropics, Bonell M, , Bruijnzeel LA (eds).Cambridge University Press: Cambridge, UK; 314-406.

Bonell M. 2010. The impacts of global change in the humid tropics: Selected rainfall-runoff issues linked with tropical forest-land management. Irrigation and Drainage Systems 24 (3-4): 279-325 DOI: 10.1007/s10795-010-9104-8

Bosch JM, Hewlett JD. 1982. A review of catchment experiments to determine the effect of vegetation changes on water yield and evapotranspiration. Journal of Hydrology 55: 323 DOI: 10.1016/0022-1694(82)90117-2

Brand WA, Coplen TB, Vog1 J, Rosner M, Prohaska T. 2014. Assessment of international reference materials for isotope-ratio analysis (IUPAC technical report). Pure and Applied Chemistry 86 (3): 425-467 DOI: 10.1515/pac-2013-1023

Brantley SL, Goldhaber MB, Vala Ragnarsdottir K. 2007. Crossing disciplines and scales to understand the critical zone. Elements 3 (5): 307-314 DOI: 10.2113/gselements.3.5.307

Brantley SL, Lebedeva MI, Balashov VN, Singha K, Sullivan PL, Stinchcomb G. 2017. Toward a conceptual model relating chemical reaction fronts to water flow paths in hills. Geomorphology 277: 100-117 DOI: 10.1016/j.geomorph.2016.09.027 
Brooks PD, Chorover J, Fan Y, Godsey SE, Maxwell RM, McNamara JP, Tague C. 2015. Hydrological partitioning in the critical zone: Recent advances and opportunities for developing transferable understanding of water cycle dynamics. Water Resources Research 51: 6973-6987 DOI: 10.1002/ 2015WR017039

Brown AE, Zhang L, McMahon TA, Western AW, Vertessy RA. 2005. A review of paired catchment studies for determining changes in water yield resulting from alterations in vegetation. Journal of Hydrology 310 (1-4): 28-61 DOI: 10.1016/j.jhydrol.2004.12.010

Bruijnzeel LA. 1989. (De)forestation and dry season flow in the tropics: a closer look. Journal of Tropical Forest Science 1 (3): 229-243

Bruijnzeel LA. 2004. Hydrological functions of tropical forests: Not seeing the soil for the trees? DOI: 10.1016/j.agee.2004.01.015

Buttle JM. 1994. Isotope hydrograph separations and rapid delivery of pre-event water from drainage basins. Progress in Physical Geography 18 (1): 16-41 DOI: $10.1177 / 030913339401800102$

Caner L, Radtke LM, Vignol-Lelarge ML, Inda A V., Bortoluzzi EC, Mexias AS. 2014. Basalt and rhyo-dacite weathering and soil clay formation under subtropical climate in southern Brazil. Geoderma 235-236: 100-112 DOI: 10.1016/j.geoderma.2014.06.024

Chandler DG. 2006. Reversibility of forest conversion impacts on water budgets in tropical karst terrain. Forest Ecology and Management 224 (1-2): 95-103 DOI: 10.1016/j.foreco.2005.12.010

Chappell NA, Sherlock M, Bidin K, Macdonald R, Najman Y, Davies G. 2007. Runoff Processes in Southeast Asia: Role of Soil, Regolith, and Rock Type. In Forest Environments in the Mekong River Basin, Sawada H, , Araki M, , Chappell NA, , LaFrankie J V, , Shimizu A (eds).Springer Japan: Tokyo; 3-23. DOI: 10.1007/978-4431-46503-4_1

Chaves J, Neill C, Germer S, Neto SG, Krusche A, Elsenbeer H. 2008. Land management impacts on runoff sources in small Amazon watersheds. Hydrological Processes 22 (12): 1766-1775 DOI: 10.1002/hyp.6803

Clymans W, Govers G, Frot E, Ronchi B, Van Wesemael B, Struyf E. 2013. Temporal dynamics of bio-available Si fluxes in a temperate forested catchment (Meerdaal forest, Belgium). Biogeochemistry 116 (1-3): 275-291 DOI: 10.1007/s10533-013-9858-9

Conley DJ, Likens GE, Buso DC, Saccone L, Bailey SW, Johnson CE. 2008. Deforestation causes increased dissolved silicate losses in the Hubbard Brook Experimental Forest. Global Change Biology 14 (11): 2548-2554 DOI: 10.1111/j.1365-2486.2008.01667.x

Dias LCP, Macedo MN, Costa MH, Coe MT, Neill C. 2015. Effects of land cover change on evapotranspiration and streamflow of small catchments in the Upper Xingu River Basin, Central Brazil. Journal of Hydrology: Regional Studies 4: 108-122 DOI: 10.1016/j.ejrh.2015.05.010

Don A, Schumacher J, Freibauer A. 2011. Impact of tropical land-use change on soil organic carbon stocks - a meta-analysis. Global Change Biology 17 (4): 1658-1670 DOI: 10.1111/j.1365-2486.2010.02336.x

Eibl B, Fernandez RA, Kozarik JC, Lupi A, Montagnini F, Nozzi D. 2000. Agroforestry systems with Ilex paraguariensis (American holly or yerba mate) and native timber trees 
on small farms in Misiones, Argentina. Agroforestry Systems 48 (1): 1-8 DOI: 10.1023/A:1006299920574

Elsenbeer H, Vertessy RA. 2000. Stormflow generation and flowpath characteristics in an Amazonian rainforest catchment. Hydrological Processes 14 (14): 2367-2381 DOI: 10.1002/1099-1085(20001015)14:14<2367::AID-HYP107>3.0.CO;2-H

ESRI. 2013. ArcGIS 10.2

FAO. 2005. New_LocClim: local climate estimator. Version 1.10. Environmental and Natural Resources, Working Paper 20.

FAO. 2006. Guidelines for Soil Description. Food and Agriculture Organization: Rome, Italy.

Foley J a, Defries R, Asner GP, Barford C, Bonan G, Carpenter SR, Chapin FS, Coe MT, Daily GC, Gibbs HK, et al. 2005. Global consequences of land use. Science (New York, N.Y.) 309 (5734): 570-4 DOI: 10.1126/science.1111772

Van Gaelen N, Verheyen D, Ronchi B, Struyf E, Govers G, Vanderborght J, Diels J. 2014. Identifying the Transport Pathways of Dissolved Organic Carbon in Contrasting Catchments. Vadose Zone Journal 13: 1-48 DOI: 10.2136/vzj2013.11.0199

Genereux D. 1998. Quantifying uncertainty in tracer-based hydrograph separations. Water Resources Research 34 (4): 915-919 DOI: 10.1029/98WR00010

Germer S, Neill C, Krusche A V., Elsenbeer H. 2010. Influence of land-use change on nearsurface hydrological processes: Undisturbed forest to pasture. Journal of Hydrology $\mathbf{3 8 0}$ (3-4): 473-480 DOI: 10.1016/j.jhydrol.2009.11.022

Godsey S, Elsenbeer H. 2002. The soil hydrologic response to forest regrowth: A case study from Southwestern Amazonia. Hydrological Processes 16 (7): 1519-1522 DOI: 10.1002/hyp.605

Godsey S, Elsenbeer H, Stallard R. 2004. Overland flow generation in two lithologically distinct rainforest catchments. Journal of Hydrology 295 (1-4): 276-290 DOI: 10.1016/j.jhydrol.2004.03.014

Godsey SE, Kirchner JW, Clow DW. 2009. Concentration-discharge relationships reflect chemostatic characteristics of US catchments. Hydrological Processes 23: 1844-1864 DOI: 10.1002/hyp.7315

Grieser J, Gommes R, Bernardi M. 2006. New LocClim - the Local Climate Estimator of FAO. Geophysical Research Abstracts 8 (1): 8305

Grip H, Fritsch J-M, Bruijnzeel LA. 2004. Soil and water impacts during forest conversion and stabilisation to new land use. In Forest, Water and People in the Humid Tropics, Bonell M, , Bruijnzeel LA (eds).Cambridge University Press: Cambridge, UK; 561-589.

Haines-Young R. 2009. Land use and biodiversity relationships. Land Use Policy 26S: 178186 DOI: $10.1016 /$ j.landusepol.2009.08.009

Hibbert AR. 1967. Forest Treatment Effects on Water Yield. In International Symposium For Hydrology, Sopper WE, , Lull HW (eds).Pergamon: New York, NY; 527-543. DOI: 10.1.1.545.6751

Holloway JM, Dahlgren RA. 2001. Seasonal and event-scale variations in solute chemistry for four Sierra Nevada catchments. Journal of Hydrology 250 (1-4): 106-121 DOI: 


\section{$10.1016 / \mathrm{S} 0022-1694(01) 00424-3$}

Houghton RA, House JI, Pongratz J, Van Der Werf GR, Defries RS, Hansen MC, Le Quéré C, Ramankutty N. 2012. Carbon emissions from land use and land-cover change. Biogeosciences 9 (12): 5125-5142 DOI: 10.5194/bg-9-5125-2012

Kendall C, McDonnel JJ. 1998. Isotope tracers in catchment hydrology (C Kendall and JJ McDonnel, eds). Elsevier: Amsterdam.

Kienzler PM, Naef F. 2008. Subsurface storm flow formation at different hillslopes and implications for the 'old water paradox'. Hydrological Processes 22: 104-116 DOI: 10.1002/hyp.6687

Klaus J, McDonnell JJ. 2013. Hydrograph separation using stable isotopes: Review and evaluation. Journal of Hydrology 505: 47-64 DOI: 10.1016/j.jhydrol.2013.09.006

Lal R. 2001. Soil degradation by erosion. Land Degradation and Development 12 (6): 519539 DOI: $10.1002 / \mathrm{ldr} .472$

Lambin EF, Geist HJ, Lepers E. 2003. Dynamics of Land-Use and Land-Cover Change in Tropical Regions. Annual Review of Environment and Resources 28 (1): 205-241 DOI: 10.1146/annurev.energy.28.050302.105459

Laudon H, Slaymaker O. 1997. Hydrograph separation using stable isotopes, silica and electrical conductivity: An alpine example. Journal of Hydrology 201 (1-4): 82-101 DOI: $10.1016 /$ S0022-1694(97)00030-9

Leibundgut C, Maloszewski P, Külls C. 2009. Tracers in Hydrology (C Leibundgut, P Maloszewski, and C Külls, eds). John Wiley \& Sons Ltd: Chichester, UK. DOI: $10.1002 / 9780470747148$

Lopes F. 2006. Utilização do Modelo Century para avaliar a dinâmica do Carbono do solo em uma pequena bacia hidrográfica rural.Universidade Federal do Rio Grande do Sul, Porto Alegre.

Maher K. 2010. The dependence of chemical weathering rates on fluid residence time. Earth and Planetary Science Letters 294 (1-2): 101-110 DOI: 10.1016/j.eps1.2010.03.010

Maher K. 2011. The role of fluid residence time and topographic scales in determining chemical fluxes from landscapes. Earth and Planetary Science Letters 312 (1-2): 48-58 DOI: $10.1016 /$ j.eps1.2011.09.040

MathWorks. 2015. MATLAB (2015b). The MathWorks, Inc.: Natick, Massachusetts, United States.

McDaniel PA, Regan MP, Brooks E, Boll J, Barndt S, Falen A, Young SK, Hammel JE. 2008. Linking fragipans, perched water tables, and catchment-scale hydrological processes. Catena 73 (2): 166-173 DOI: 10.1016/j.catena.2007.05.011

McDonnell J.J. 1990. A Rational For Old Water Discharge Through Macroporos in a Steep, Humid Catchment. Water Resources Research 26 (11): 2821-2832 DOI:

10.1029/WR026i011p02821

McGlynn B, McDonnell J, Stewart M, Seibert J. 2003. On the relationships between catchment scale and streamwater mean residence time. Hydrological Processes 17 (1): 175-181 DOI: 10.1002/hyp.5085 
McGlynn BL, McDonnell JJ. 2003. Quantifying the relative contributions of riparian and hillslope zones to catchment runoff. Water Resour. Res. 39 (11): 1310 DOI: 10.1029/2003wr002091

McGuire KJ, McDonnell JJ, Weiler M, Kendall C, McGlynn BL, Welker JM, Seibert J. 2005. The role of topography on catchment-scale water residence time. Water Resources Research 41 (5): 1-14 DOI: 10.1029/2004WR003657

McIntosh JC, Schaumberg C, Perdrial J, Harpold A, Vásquez-Ortega A, Rasmussen C, Vinson D, Zapata-Rios X, Brooks PD, Meixner T, et al. 2017. Geochemical evolution of the Critical Zone across variable time scales informs concentration-discharge relationships: Jemez River Basin Critical Zone Observatory. Water Resources Research 53: 4169-4196 DOI: 10.1002/2016WR019712.

Merten GH, Minella JPG. 2006. Impact on sediment yield due to the intensification of tobacco production in a catchment in Southern Brazil. Ciência Rural 36 (2): 669-672 DOI: $10.1590 / \mathrm{S} 0103-84782006000200050$

Merten GH, Minella JPG, Moro M, Maier C, Cassol EA, Walling DE, Clarke RT, Reichert JM. 2010. The effects of soil conservation on sediment yield and sediment source dynamics in a catchment in southern Brazil. Sediment Dynamics for a Changing Future 337 (June): 59-67

Minella JPG, Merten GH, Reichert JM, Clarke RT. 2008a. Estimating suspended sediment concentrations from turbidity measurements and the calibration problem. Hydrological Processes 22: 1819-1830 DOI: 10.1002/hyp.6763

Minella JPG, Merten GH, Walling DE, Reichert JM. 2009. Changing sediment yield as an indicator of improved soil management practices in southern Brazil. Catena 79 (3): 228 236 DOI: $10.1016 /$ j.catena.2009.02.020

Minella JPG, Walling DE, Merten GH. 2008b. Combining sediment source tracing techniques with traditional monitoring to assess the impact of improved land management on catchment sediment yields. Journal of Hydrology 348 (3-4): 546-563 DOI: 10.1016/j.jhydrol.2007.10.026

Molina A, Vanacker V, Balthazar V, Mora D, Govers G. 2012. Complex land cover change, water and sediment yield in a degraded andean environment. Journal of Hydrology 472 473: 25-35 DOI: 10.1016/j.jhydrol.2012.09.012

Montgomery DR. 1994. Road surface drainage, channel initiation, and slope instability. Water Resources Research 30 (6): 1925-1932 DOI: 10.1029/94WR00538

Moraes JM, Schuler AE, Dunne T, Figueiredo R deO, Victoria RL. 2006. Water storage and runoff processes in plinthic soils under forest and pasture in Eastern Amazonia. Hydrological Processes 20 (12): 2509-2526 DOI: 10.1002/hyp.6213

Morellato LPC, Haddad CFB. 2000. Introduction: The Brazilian Atlantic Forest. Biotropica 32 (4b): 786-792 DOI: 10.1111/j.1744-7429.2000.tb00618.x

Muñoz-Villers LE, McDonnell JJ. 2013. Land use change effects on runoff generation in a humid tropical montane cloud forest region. Hydrology and Earth System Sciences 17 (9): 3543-3560 DOI: 10.5194/hess-17-3543-2013

Niedzialek JM, Ogden FL. 2012. First-order catchment mass balance during the wet season in the Panama Canal Watershed. Journal of Hydrology 462-463: 77-86 DOI: 
10.1016/j.jhydrol.2010.07.044

Ramon R, Minella JPG, Merten GH, de Barros CAP, Canale T. 2017. Kinetic energy estimation by rainfall intensity and its usefulness in predicting hydrosedimentological variables in a small rural catchment in southern Brazil. Catena 148: 176-184 DOI: 10.1016/j.catena.2016.07.015

Renne PR, Ernesto M, Pacca IG, Coe RS, Glen J, Prevot M, Perrin M. 1992. The age of Parana flood vulcanism, rifting of Gondwanaland, and the Jurassic-Crectaceous boundary. Science 258: 975-979 DOI: 10.1126/science.258.5084.975

Ribeiro MC, Metzger JP, Martensen AC, Ponzoni FJ, Hirota MM. 2009. The Brazilian Atlantic Forest: How much is left, and how is the remaining forest distributed? Implications for conservation. Biological Conservation 142 (6): 1141-1153 DOI: 10.1016/j.biocon.2009.02.021

Salazar A, Baldi G, Hirota M, Syktus J, McAlpine C. 2015. Land use and land cover change impacts on the regional climate of non-Amazonian South America: A review. Global and Planetary Change 128: 103-119 DOI: 10.1016/j.gloplacha.2015.02.009

Salemi LF, Groppo JD, Trevisan R, de Moraes JM, de Barros Ferraz SF, Villani JP, DuarteNeto PJ, Martinelli LA. 2013. Land-use change in the Atlantic rainforest region: Consequences for the hydrology of small catchments. Journal of Hydrology 499: 100 109 DOI: 10.1016/j.jhydrol.2013.06.049

Sandstrom K. 1996. Hydrochemical deciphering of streamflow generation in semi-arid East Africa. Hydrological Processes 10 (5): 703-720

Sidle RC, Noguchi S, Tsuboyama Y, Laursen K. 2001. A conceptual model of preferential flow systems in forested hillslopes: Evidence of self-organization. Hydrological Processes 15 (10): 1675-1692 DOI: 10.1002/hyp.233

Sklash MG. 1990. Environmental isotope studies of storm and snowmelt runoff generation. In Process Studies in Hillslope Hydrology, Anderson MG, , Burt TP (eds).Wiley: Chichester, UK; 401-435.

Stewart MK, Mehlhorn J, Elliott S. 2007. Hydrometric and natural tracer (oxygen-18, silica, tritium and sulphur hexafluoride) evidence for a dominant groundwater contribution to Pukemanga Stream, New Zealand. Hydrological Processes 21 (24): 3340-3356 DOI: 10.1002/hyp.6557

Struyf E, Conley DJ. 2012. Emerging understanding of the ecosystem silica filter. Biogeochemistry 107 (1-3): 9-18 DOI: 10.1007/s10533-011-9590-2

Uchida T, Kosugi KNI, Mizuyama T. 2001. Effects of pipeflow on hydrological process and its relation to landslide: A review of pipeflow studies in forested headwater catchments. Hydrological Processes 15 (11): 2151-2174 DOI: 10.1002/hyp.281

Uhlenbrook S, Didszun J, Jochen Wenninger. 2008. Source areas and mixing of runoff components at the hillslope scale — a multi-technical approach. Hydrological Sciences Journal 53 (4): 741-753 DOI: 10.1623/hysj.53.4.741

Unzué-Belmonte D, Ameijeiras-Mariño Y, Opfergelt S, Cornelis J-T, Barão L, Minella J, Meire P, Struyf E. 2017. Land use change affects biogenic silica pool distribution in a subtropical soil toposequence. Solid Earth Discussions (February): 1-20 DOI: $10.5194 / \mathrm{se}-2017-21$ 
Vanacker V, von Blanckenburg F, Govers G, Molina A, Poesen J, Deckers J, Kubik P. 2007. Restoring dense vegetation can slow mountain erosion to near natural benchmark levels. Geology 35 (4): 303-306 DOI: 10.1130/G23109A.1

Vieira BC, Salgado AAR, Santos LJC. 2015. Landscape and Landforms of Brazil (BC Vieira, AAR Salgado, and LJC Santos, eds). Springer.

Webb TJ, Woodward FI, Hannah L, Gaston KJ. 2005. Forest Cover - Rainfall Relationships in a Biodiversity Hotspot: the Atlantic Forest of Brazil. Ecological Society of America 15 (6): 1968-1983 DOI: 10.1890/04-1675

Zhou GY, Morris JD, Yan JH, Yu ZY, Peng SL. 2002. Hidrological impact of reafforestation with eucalipts and indigenous species: a case study in Southern China. Forest Ecology and Management 167 (1-3): 209-222 DOI: Pii S0378-1127(01)00694-6\rDoi $10.1016 / \mathrm{S} 0378-1127(01) 00694-6$

Ziegler AD, Giambelluca TW, Tran LT, Vana TT, Nullet MA, Fox J, Vien TD, Pinthong J, Maxwell JF, Evett S. 2004. Hydrological consequences of landscape fragmentation in mountainous northern Vietnam: Evidence of accelerated overland flow generation. Journal of Hydrology 287 (1-4): 124-146 DOI: 10.1016/j.jhydrol.2003.09.027

Zimmermann B, Elsenbeer H, De Moraes JM. 2006. The influence of land-use changes on soil hydraulic properties: Implications for runoff generation. Forest Ecology and Management 222 (1-3): 29-38 DOI: 10.1016/j.foreco.2005.10.070

\section{Figures}

(a) ILO

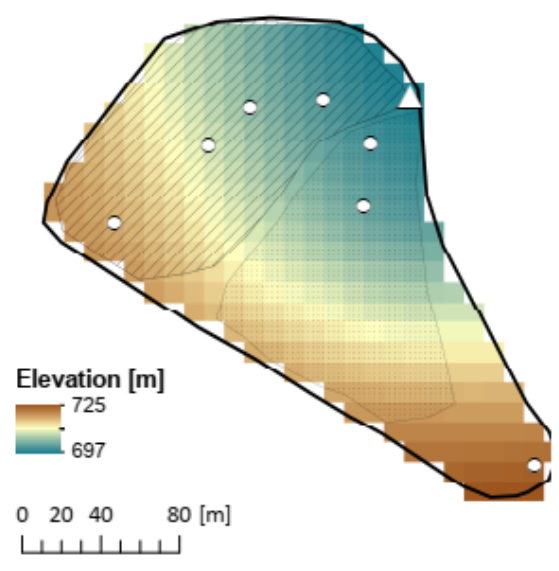

- Stream gauging stations

- Suction cups and Piezometers

ZID Gentle field (FOG, ARG)

Steep field (FOS, ARS)

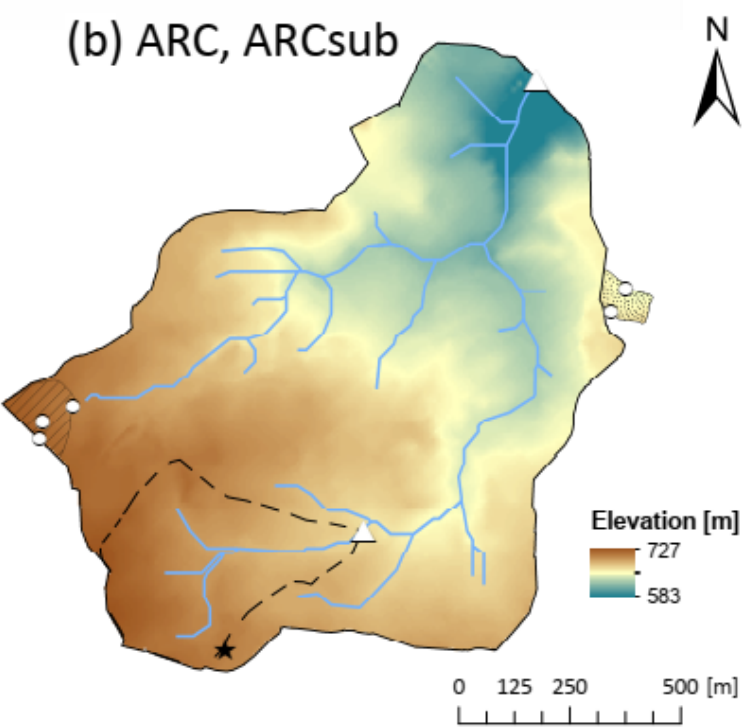

$\begin{array}{ll}\square & \text { Catchment (FOC, ARC) } \\ \square & \text { Sub-catchment (ARCsub) } \\ -\quad \text { Drainage } \\ \star \quad \text { Weather station }\end{array}$

Fig. 1 - Detailed overview of A) the forested catchment (FOC) and B) the agricultural catchment (ARC) and its subcatchment (ARCsub). Interpolation of regional topographic curves with ArcGIS (ESRI, 2013) yielded the digital elevation model (DEM) for FOC. A 5m 
resolution DEM was obtained for ARC and ARCsub using a RealTek GPS with a mobile antenna (Realtek Semiconductor Corp., Hsinchu, Taiwan).

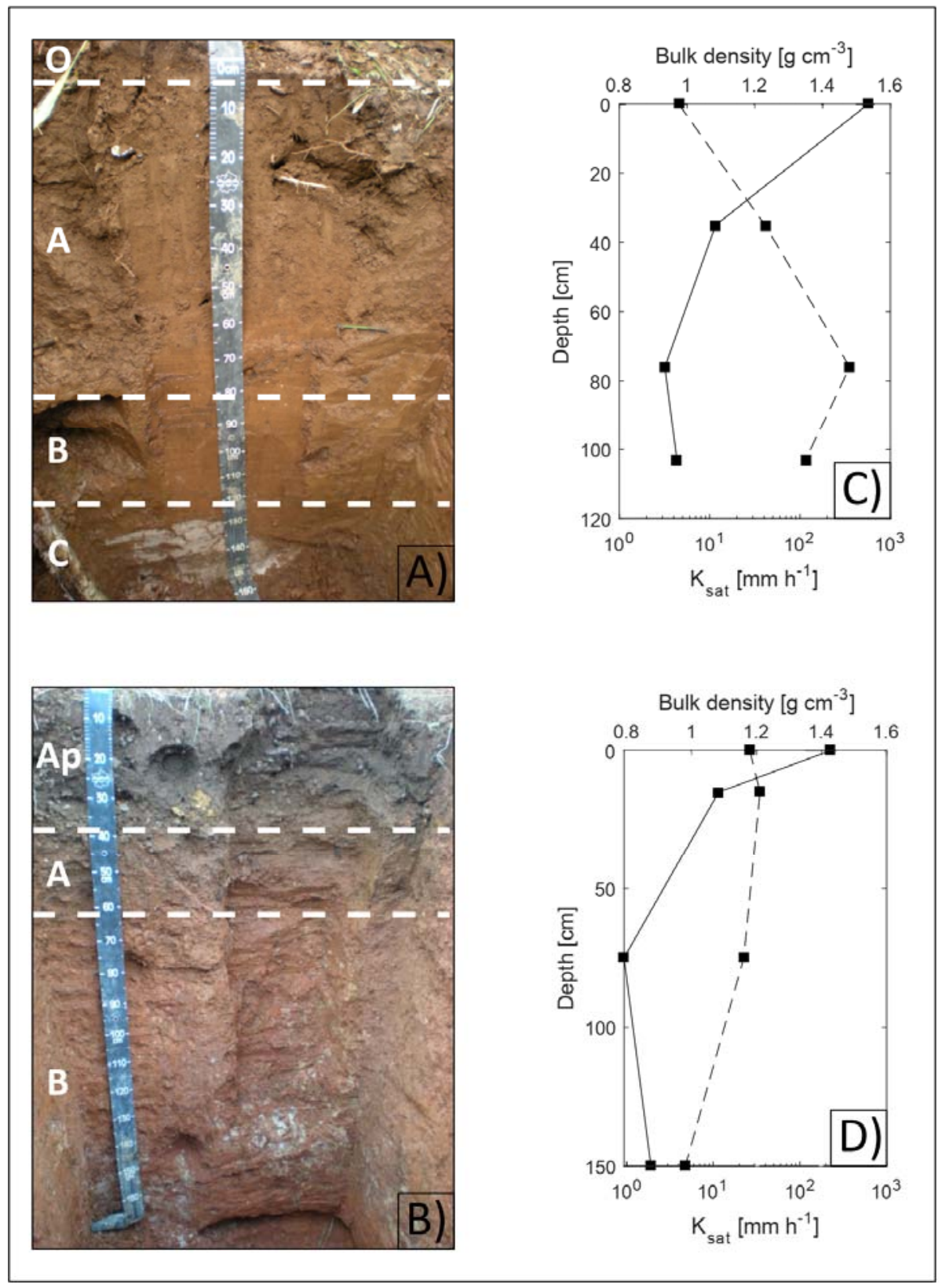

Fig. 2 - A, B) Typical soil profiles of the ILO forested catchment and ARC agricultural catchment, respectively. The letters on the profiles correspond to different soil horizons classified according to the FAO guidelines (FAO, 2006). C, D) Hydraulic conductivity (Ksat) and bulk density variations with depths of the soil profiles shown on A) and B), respectively. 

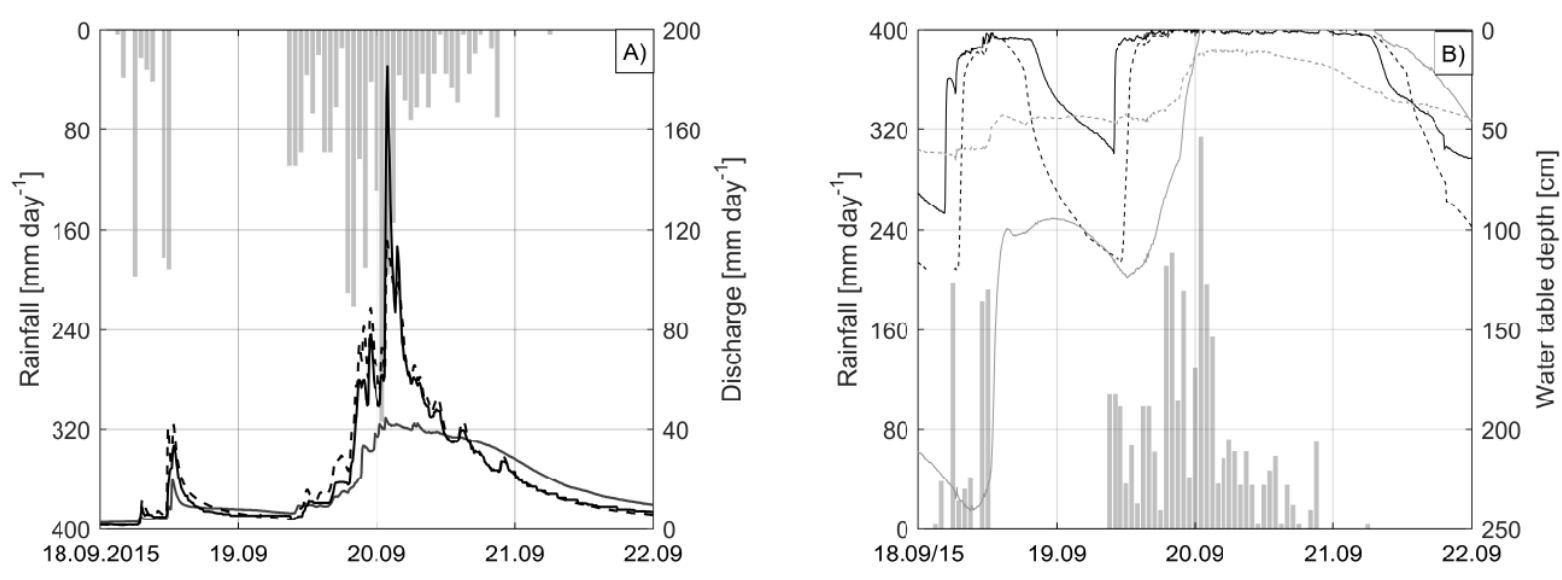

Fig. 3 - A) Stream discharge standardized by the catchment area for FOC (grey line), ARC (black line) and ARCsub (dashed black line); B) Water table depth measured within observation wells at ARGB (grey line), ARGT (dashed grey line), FOGB (black line) and FOSB (dashed black line). On both graphs, the rainfall amount was measured at the ARC meteorological station (grey bars).
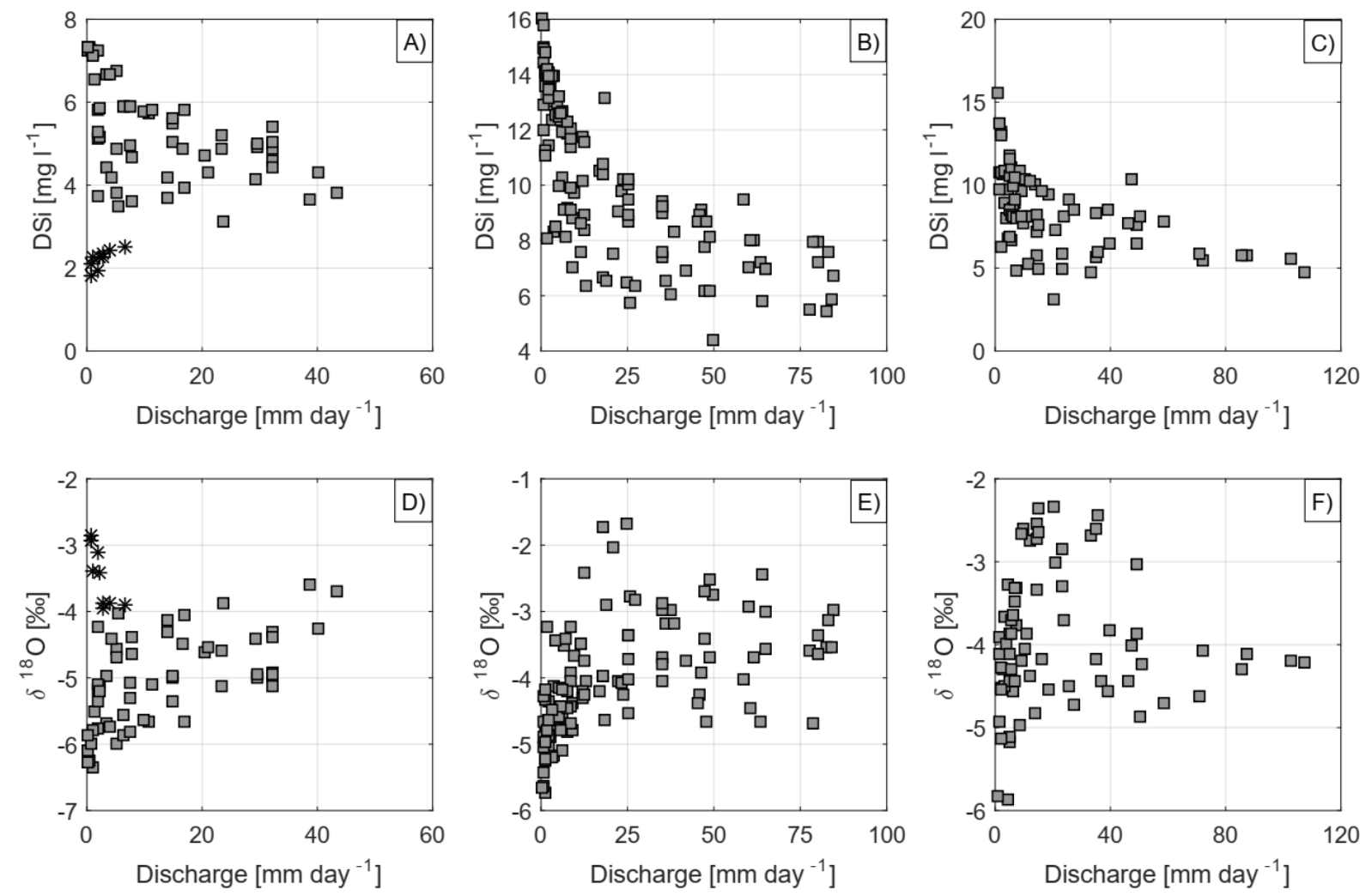

Fig. 4 - Scatter plots of discharge versus stream DSi for A) FOC, B) ARCsub and C) ARC, and discharge versus stream $\delta^{18} \mathrm{O}$ for D) FOC, E) ARCsub and F) ARC. Samples noted with * for FOC correspond to specific events described in section 3.2. 

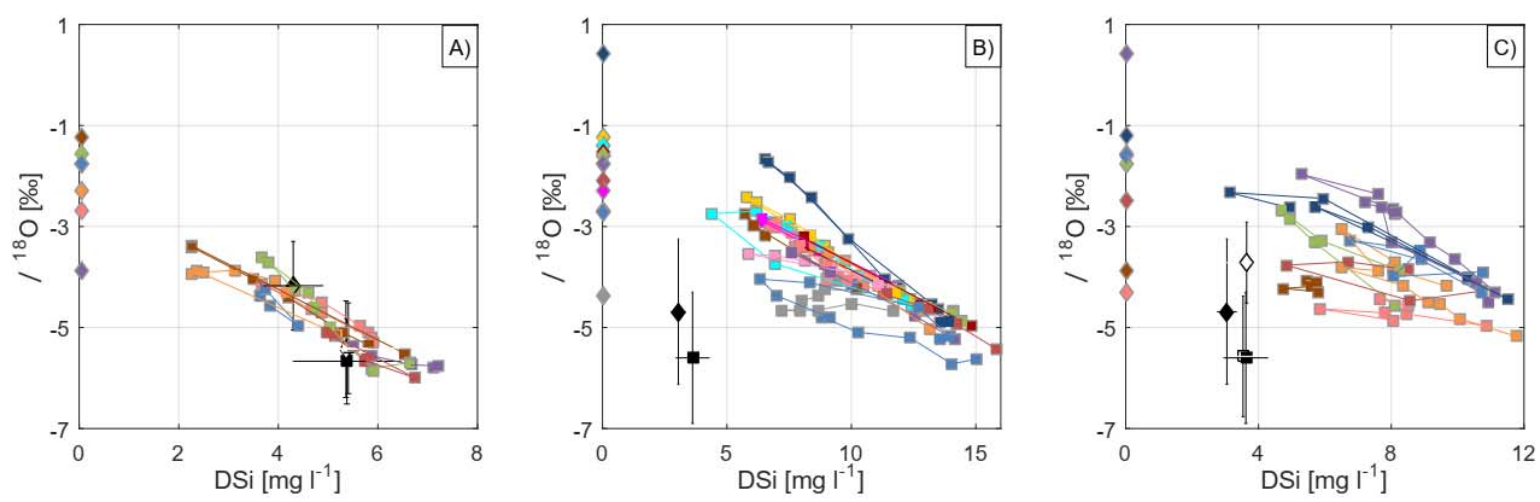

Fig. 5 - Scatter plots of measured DSi versus $\delta^{18}$ O signature for A) FOC, B) ARCsub and C) ARC. The different hydrological components represented are: the stream water (coloured squares), rainwater (coloured diamonds), subsurface water (black and white diamonds), pore water (black and white squares). Gentle slopes (ARG, FOG) are represented by black symbols and steep slopes (ARS, FOS) by white symbols. ARS is not shown for ARCsub as there are no steep slopes contributing to that catchment. For more clarity, not all rainfall samples are presented on this figure. We selected the rain samples corresponding to the beginning of each rainfall event. The error bars are the calculated standard deviations for the corresponding hydrological component. For rain and stream samples, the colours correspond to different rainfall events.

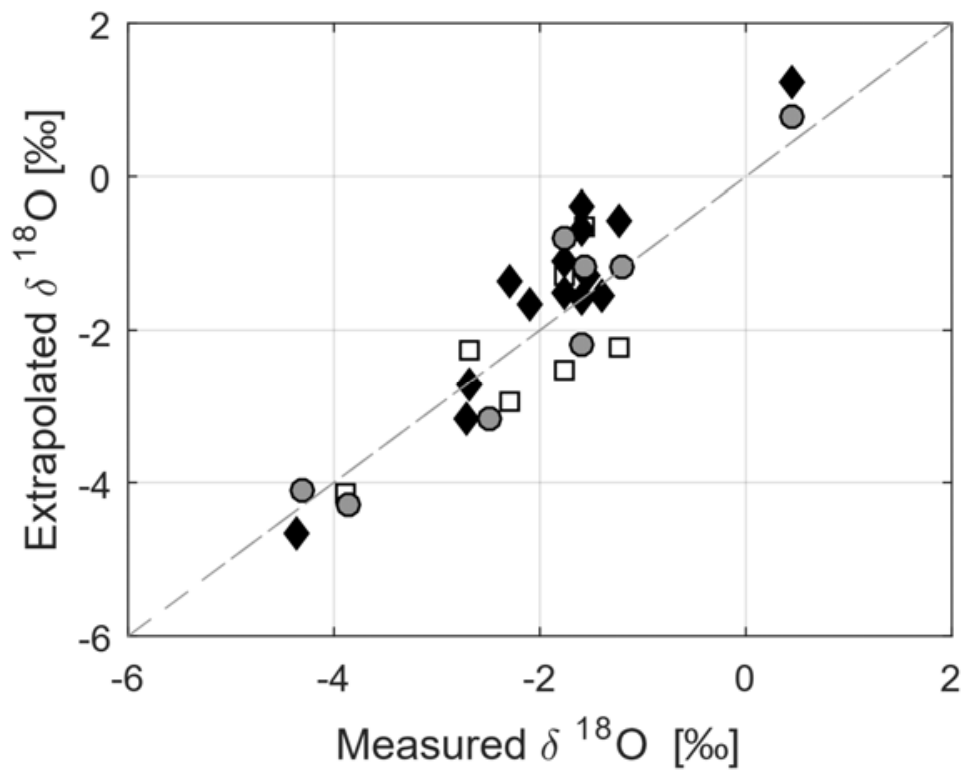

Fig. 6 - Measured versus extrapolated rainfall $\delta^{18} \mathrm{O}$ signature for FOC (white squares), ARCsub (black diamonds) and ARC (grey circles). The 1:1 line is indicated by a dashed line. 

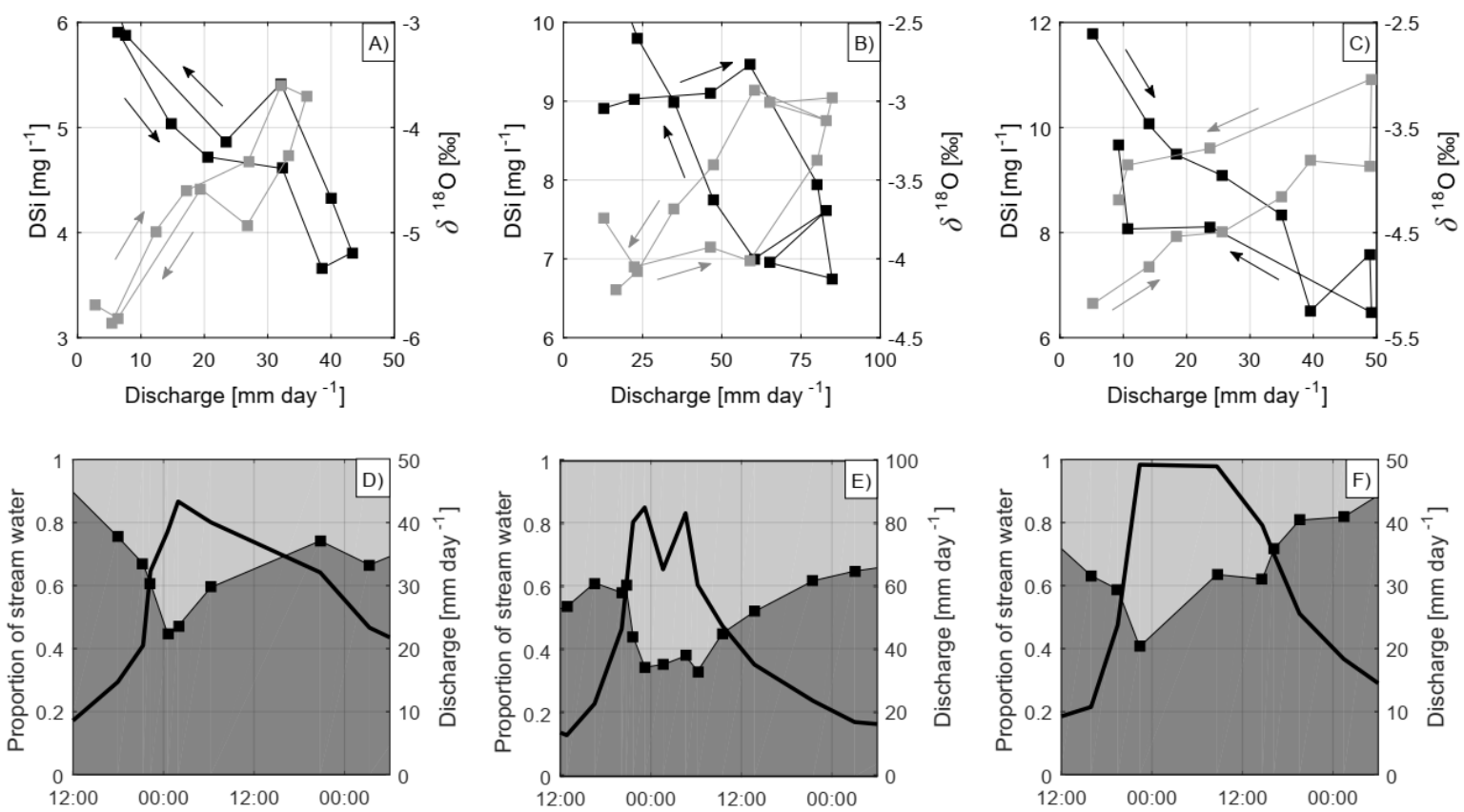

Fig. 7 - Hysteresis loops of DSi (black line) and $\delta^{18} \mathrm{O}$ (grey line) in function of the discharge for A) FOC, B) ARCsub and C) ARC. The arrows indicate the direction of the hysteresis loops and bring additional information regarding water pathways. Results of the twocomponent hydrograph separation for D) FOC, E) ARCsub and F) ARC between the 19/09/2015 12:00 and the 21/09/2015 06:00 with the total stream discharge (black line), the sampling time (squares) and the contribution of pre-event water (dark grey area) and event water (light grey area).
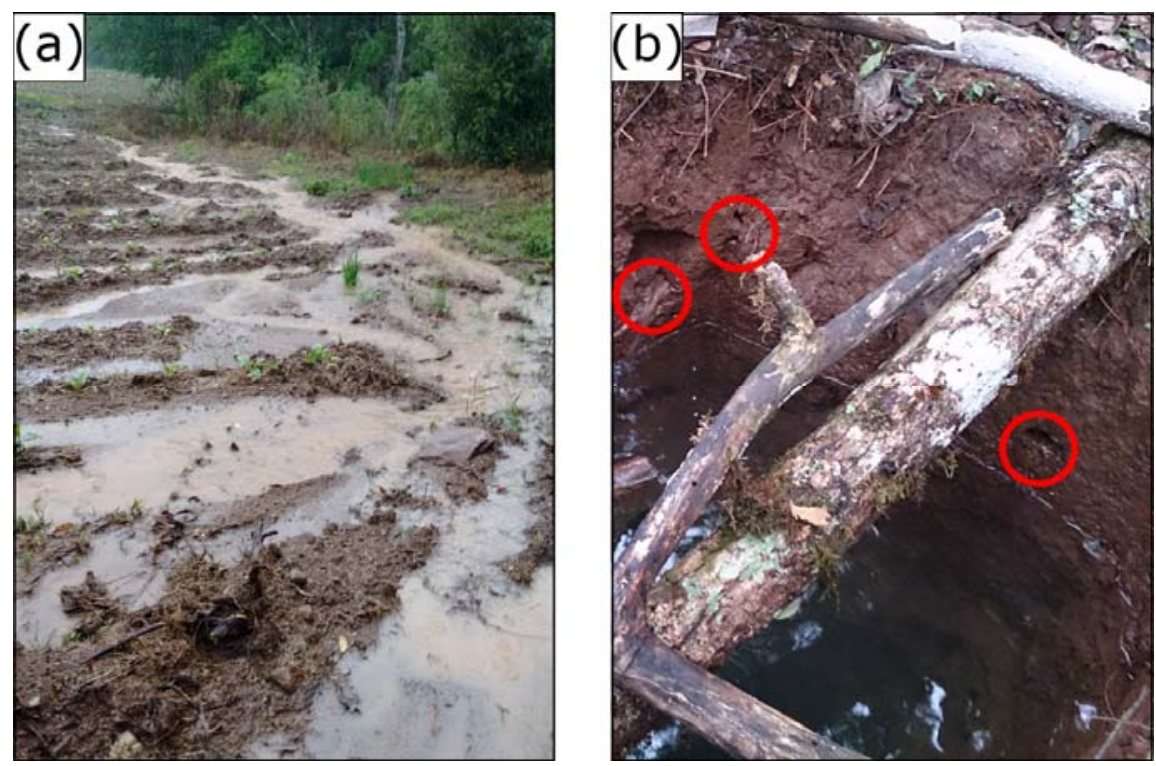

Fig. 8 - A) Surface runoff in ARC; B) Concentred subsurface flow in macropores in an open soil pit in FOC. 


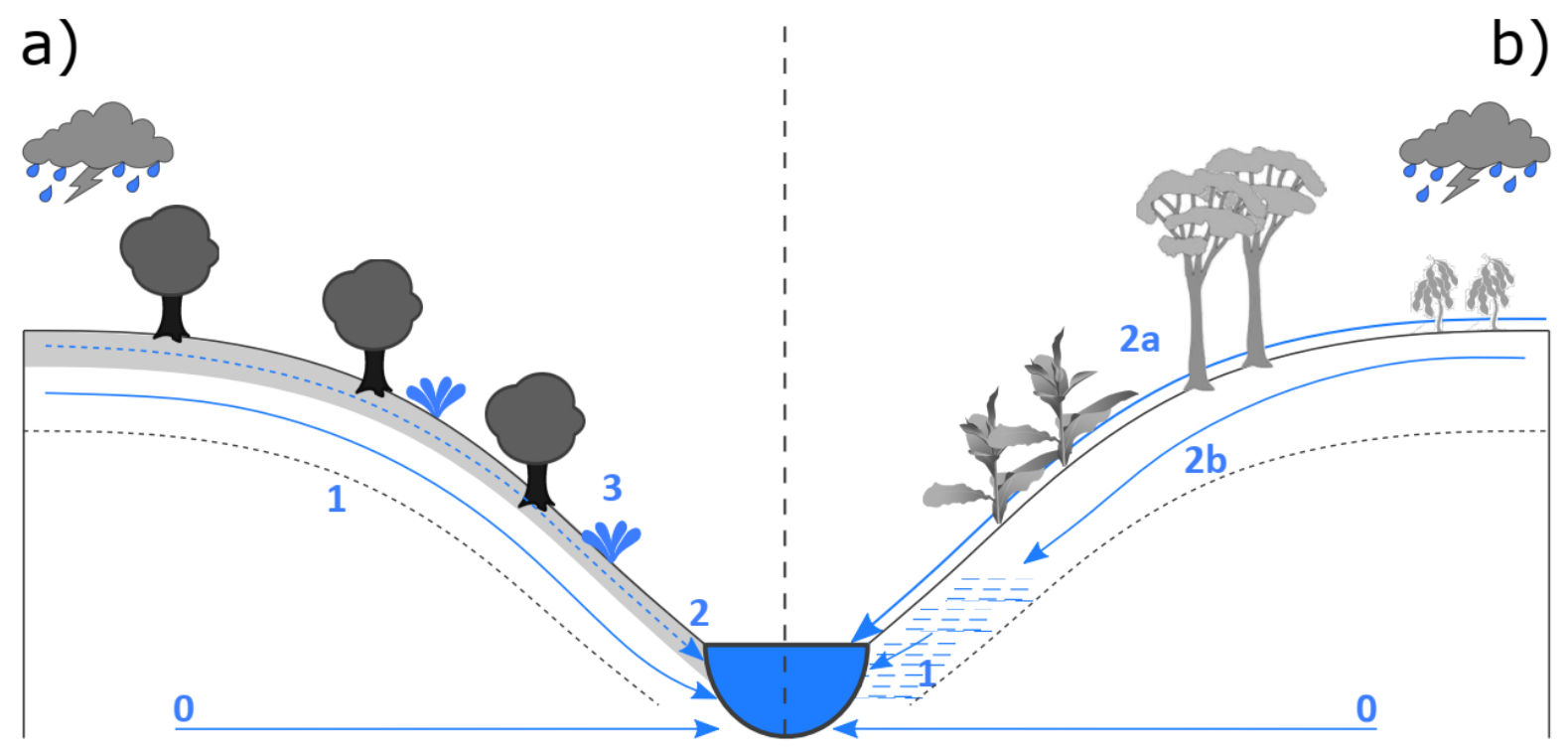

Fig. 9 - A) Conceptual model of water pathways in the forested catchment: 0) Baseflow (preevent water), 1) Event water delivery through subsurface flow, 2) Pre-event water delivery through topsoil pore water mobilization, and 3) Saturation overland flow. B) Conceptual model of water pathways in the agricultural catchments: 1) Rapid old water delivery from near-stream areas, 2a) Event water delivery through surface runoff, 2b) Event water delivery through subsurface flow. See section 4.2 for further descriptions.

\section{Tables}

Table 1 - Summary of the properties of the field selected for the installation of the monitoring and sampling equipment. The soil properties are averages from samples taken at $10 \mathrm{~cm}$ depthinterval in 9 soil pits located at 3 different positions (bottom, middle, top) in each field. The texture fractions were obtained by laser diffraction grain-size analysis using a Coulter LS-100 (Beuselinck et al., 1998).

\begin{tabular}{|c|c|c|c|c|c|c|c|c|c|}
\hline \multirow{2}{*}{$\begin{array}{l}\text { Dominant } \\
\text { Land Use }\end{array}$} & \multirow{2}{*}{\multicolumn{2}{|c|}{ Fields }} & & Silt & Sand & $\begin{array}{l}\text { Bulk Density } \\
(\text { depth }<30 \mathrm{~cm})\end{array}$ & Avg. slope & \multirow{2}{*}{\multicolumn{2}{|c|}{ Positions }} \\
\hline & & & $\%<2 \mu m$ & $2 \mu m<\%<60 \mu m$ & $\begin{array}{c}60 \mu \mathrm{m}< \\
\%\end{array}$ & g. $\mathrm{cm}^{-3}$ & $\circ$ & & \\
\hline \multirow{2}{*}{$\begin{array}{l}\text { Arable } \\
\text { land }\end{array}$} & Gentle & (ARG) & $22.4 \pm 6.4$ & $60.4 \pm 5.8$ & $17.2 \pm 5.9$ & $1.32 \pm 0.13$ & $5.9 \pm 1.2$ & $\begin{array}{l}\text { Bottom } \\
\text { Top }\end{array}$ & $\begin{array}{l}\text { (ARGB) } \\
\text { (ARGT) }\end{array}$ \\
\hline & Steep & (ARS) & $16.9 \pm 3.0$ & $58.7 \pm 7.2$ & $24.4 \pm 9.3$ & $1.17 \pm 0.09$ & $11.9 \pm 4.7$ & $\begin{array}{l}\text { Bottom } \\
\text { Top }\end{array}$ & $\begin{array}{l}\text { (ARSB) } \\
\text { (ARST) }\end{array}$ \\
\hline \multirow{2}{*}{ Forest } & Gentle & (FOG) & $17.2 \pm 3.5$ & $69.6 \pm 4.8$ & $13.2 \pm 5.6$ & $1.06 \pm 0.14$ & $8.7 \pm 2.4$ & $\begin{array}{l}\text { Bottom } \\
\text { Top }\end{array}$ & $\begin{array}{l}\text { (FOGB) } \\
(\text { FOGT) }\end{array}$ \\
\hline & Steep & $(\mathrm{FOS})$ & $16.6 \pm 3.1$ & $69.7 \pm 4.0$ & $13.7 \pm 5.2$ & $0.92 \pm 0.17$ & $14.1 \pm 5.0$ & $\begin{array}{l}\text { Bottom } \\
\text { Top }\end{array}$ & $\begin{array}{l}(\mathrm{FOSB}) \\
(\mathrm{FOST})\end{array}$ \\
\hline
\end{tabular}

